\title{
Clomazone and oxyfluorfen for weed control in transplanted cabbage (Brassica oleracea L. $)^{1,2}$
}

\author{
Nelson Semidey.3 \\ J. Agric. Univ. P.R. 81(3-4):203-210 (1997)
}

\begin{abstract}
Two field experiments were conducted in 1992-93 and 1994 at Juana Diaz, Puerto Rico, to evaluate clomazone, oxyfluorfen, and prometryn as preplant herbicides in cabbage. After three weeks, clomazone (1.12 and 2.24 $\mathrm{kg} \mathrm{ai} / \mathrm{ha})$, oxyfluorfen $(0.28$ and $0.56 \mathrm{~kg}$ ai/ha), and prometryn (2.0 and $4.0 \mathrm{~kg}$ ai/ha) reduced weed density by more than $67 \%$ and $90 \%$ in $1992-93$ and 1994 , respectively. At the lower rate, clomazone and oxyfluorfen caused $15 \%$ to $25 \%$ injury to cabbage when evaluated after three weeks, and $2 \%$ to $10 \%$ after six weeks. Prometryn caused more than $65 \%$ injury and reduced cabbage yield by more than $84 \%$. Cabbage treated with clomazone at both rates and oxyfluorfen at $0.56 \mathrm{~kg}$ ai/ha produced yields similar to that of the handweeded check $(39,980 \mathrm{~kg} / \mathrm{ha})$ in 1992-93. Interference to cabbage was caused mostly by purple nutsedge (Cyperus rotundus L.) in 1994.
\end{abstract}

Key words: cabbage, clomazone, oxyfluorfen, prometryn, weed control

\section{RESUMEN}

\section{Clomazone y oxyfluorfen para controlar malezas en repollo (Brassica oleracea L.) de trasplante}

Durante 1992-93 y 1994 se realizaron dos experimentos de campo para evaluar clomazone, oxyfluorfen y prometryn como herbicidas pretrasplante en repollo. Ciomazone $(1.12$ y $2.24 \mathrm{~kg}$ ia/ha), oxyfluorfen $(0.28$ y $0.56 \mathrm{~kg} \mathrm{ia} /$ ha) y prometryn $(2.0$ y $4.0 \mathrm{~kg}$ ia/ha) redujeron la densidad total de malezas en más de $67 \%$ y $90 \%$ a las tres semanas después del trasplante del repollo en 1992-93 y 1994, respectivamente. A la dosis baja tanto el clomazone como el oxyfluorfen causaron daño al repollo; el daño varió desde moderado $(15 \%$ a $25 \%)$ cuando se evaluó a las tres semanas hasta leve $(2 \%$ a $10 \%$ ) a las seis semanas. Prometryn causó mas de $65 \%$ de daño en las plántulas de repollo y redujo el rendimiento del repollo en más del $84 \%$. El repoIlo tratado con clomazone a ambas dosis y con oxyfluorfen a $0.56 \mathrm{~kg}$ ia/ha produjo rendimientos similares al del desyerbo manual $(39,980 \mathrm{~kg} / \mathrm{ha}$ ) en 1992-93. La interferencia en el repollo fue causada mayormente por el coqui (Cyperus rotundus L.) durante el 1994.

'Manuscript submitted to Editorial Board 2 July 1996.

2The author acknowledges the technical assistance of Ariel Aponte and Ismael Reyes during the course of this research.

"Associate Weed Scientist, Crop Protection Department, Agricultural Experiment Station, HC 1 Box 11656, Lajas, PR 00667. 


\section{INTRODUCTION}

Cabbage has the potential to become a major vegetable crop in Puerto Rico. Most of the local demand is supplied from the United States (Departamento de Agricultura, 1992). Decline in local production since 1988 is attributed to insect problems, especially to damages from the diamondback moth (Plutella xylostella L.) (Alamo, 1992).

The results of a herbicide field trial indicate that weed interference represents a potential problem for cabbage production in Puerto Rico (Jackson, 1977). In this trial, crop yield declined by $85 \%$ when DCPA was not applied to cabbage. At present, DCPA is the only herbicide registered for cabbage in Puerto Rico, and its efficacy for weed control has been deficient under local conditions.

Cole crops have been somewhat tolerant to oxyfluorfen and clomazone in the United States (Scott et al., 1995; Scott and Weston, 1992). According to Herbst and Deer (1990), direct-seeded broccoli (B. oleracea var. botrytis) was marginally tolerant to several rates of oxyfluorfen that acceptably controlled broadleaf weeds. Oxyfluorfen was labeled for weed control in cabbage in 1989 and clomazone from 1990 to 1994 in the North Central United States (Hopen, 1995). Oxyfluorfen and prometryn were more than $90 \%$ effective for weeds in transplanted cabbage in Colombia (Nuñez-Almario, 1984).

The objective of this study was to evaluate the efficacy of clomazone, oxyfluorfen, and prometryn as pretransplant herbicides in cabbage.

\section{MATERLALS AND METHODS}

Two experiments were conducted at the Juana Díaz Agricultural Experiment Station in 1992-93 and 1994. The soil was a San Antón (Fine-loamy, mixed, isohyperthermic Cumulic Haplustolls) with $\mathrm{pH}$ of 7.8. Clay, silt, sand, and organic matter content was $33.9,27.9,38.2$, and $1.2 \%$, respectively.

A split-plot design with four replications was used for the arrangement of treatments in the field. Plots consisted of six 6.1-m rows spaced $0.91 \mathrm{~m}$ apart. The main plots were herbicide treatments and subplots were cabbage cultivars (Blue Vantage and Tenacity). Herbicide treatments (in $\mathrm{kg}$ ai/ha) were clomazone ( 1.12 and 2.24 ), oxyfluorfen $(0.28$ and 0.56 ), and prometryn (2.0 and 4.0). Handweeded and nonweeded treatments were also included in the experiments.

Herbicides were surface applied at the rate of $165 \mathrm{~L} /$ ha 10 December 1992 and 19 January 1994 with a $\mathrm{CO}_{2}$-pressurized backpack sprayer. Overhead irrigation was applied for $0.5 \mathrm{~h}$ immediately after herbicide application to promote herbicide activity. Cabbage seedlings were 
transplanted $30 \mathrm{~cm}$ apart five days after herbicide application each year.

Drip irrigation was applied for the first two days after cabbage planting and then twice a week until harvesting: Plots were evaluated for weed emergence and visible crop injury at three and six weeks after planting (WAP). Insects were controlled with Guthion 2 L', Lannate 90 WSP, Ambush, and Diazinon AG500.

Cabbage heads were collected at 10 and 12 WAP for yield determination. Data from each experiment were subjected to Analysis of Variance and means separated by LSD (0.05).

\section{RESULTS AND DISCUSSION}

Data were not combined over years since rainy conditions delayed cabbage planting and promoted more weed growth in 1994 than in 1992-93. Results presented are the main effects of herbicides compared either to handweeded or nonweeded treatments.

Both rates of clomazone, oxyfluorfen, and prometryn reduced total weed density by more than 67\% at three WAP in 1992-93 (Table 1). At six WAP, clomazone reduced weed density by $52 \%$ to $74 \%$, oxyfluorfen by $48 \%$ to $62 \%$; and prometryn by only $25 \%$ and $34 \%$. Clomazone and oxyfluorfen each at the lower rate caused moderate (18\% to $22 \%$ ) to low injury ( $5 \%$ to $7 \%$ ) to cabbage at three and six WAP, respectively. Visible injuries were similar in the two cultivars (data not shown).

Injury symptoms observed in cabbage foliage were chlorosis and bleaching for clomazone treatments. Leaf crinkling was observed after oxyfluorfen treatments. These injury symptoms were not evident at nine WAP (data not shown). The two rates of prometryn caused over $73 \%$ stand mortality at six WAP and cabbage yields were reduced by more than $84 \%$ as compared with yields of the handweeded treatment. Cabbage treated with clomazone (1.12 and $2.24 \mathrm{~kg}$ ai/ha) and oxyfluorfen $(0.56 \mathrm{~kg}$ ai/ha) produced yields similar to that of the handweeded treatment.

Data on total weed density and visible crop injury in response to herbicides in 1994 were similar to data recorded in 1992-93 (Table 2). For 1994, all herbicide treatments reduced weed density by $91 \%$ or more at three WAP as compared to the nonweeded treatment. Clomazone $(1.12 \mathrm{~kg}$ ai/ha) and oxyfluorfen $(0.28 \mathrm{~kg}$ ai/ha) reduced weed density by $83 \%$ and $84 \%$, respectively, at six WAP.

Trade names in this publication are used only to provide specific information. Mention of trade names does not constitute a warranty of materials by the UPR-AES, nor is this mention a statement of preference over other materials. 
TABLE 1.-Effect of pre-transplant treatments on total weed density, visible injury, and cabbage yield in. $1992-93$ at Juana Diaz, Puerto Rico.

\begin{tabular}{|c|c|c|c|c|c|c|}
\hline \multirow[b]{2}{*}{ Treatment } & \multirow[b]{2}{*}{ Rate } & \multicolumn{2}{|c|}{ Total weed density } & \multicolumn{2}{|c|}{ Visible injury: } & \multirow[b]{2}{*}{ Cabbage yield } \\
\hline & & $3 \mathrm{WAP}^{2}$ & $6 \mathrm{WAP}$ & 3 WAP & $6 \mathrm{WAP}$ & \\
\hline & $\mathrm{kg}$ ai/ha & \multicolumn{2}{|c|}{ Plants/0.5 $\mathrm{m}^{2}(\%)^{3}$} & $\ldots . . . . . . . . .$. & ......... & $\mathrm{kg} / \mathrm{ha}$ \\
\hline Clomazone & 1.12 & $27(67)$ & $29(52)$ & 22 & 7 & 33,450 \\
\hline Clomazone & 2.24 & $15(82)$ & $16(74)$ & 37 & 14 & 37,160 \\
\hline Oxyfluorfen & 0.28 & $13(84)$ & $32(48)$ & 18 & 5 & 24,630 \\
\hline Oxyfluorfen & 0.56 & $9(89)$ & $23(62)$ & 28 & 29 & 30,200 \\
\hline Prometryn & 2.00 & $6(93)$ & $46(25)$ & 77 & 73 & 6.460 \\
\hline Prometryn & 4.00 & $6(93)$ & $40(34)$ & 98 & 98 & 280 \\
\hline Handweeded & - & $0(100)$ & $11(82)$ & 0 & 0 & 39,980 \\
\hline Nonweeded & - & $83(0)$ & $61(0)$ & 0 & 0 & 880 \\
\hline $\mathrm{LSD}(0.05)$ & & 21 & 22 & 14 & 20 & 10.140 \\
\hline
\end{tabular}

Visual rating scale from 0 to 100 , with $0=$ no injury and $100=$ complete mortality.

${ }^{2}$ WAP $=$ weeks after planting.

Percentage weed reduction as calculated from the nonweeded treatment. 
TABLE 2. -Effect of pre-transplant treatments on weed density, visible injury, and cabbage yield in 1994 at Juana Diaz, Puerto Rico.

\begin{tabular}{|c|c|c|c|c|c|c|}
\hline \multirow[b]{2}{*}{ Treatment } & \multirow[b]{2}{*}{ Rate } & \multicolumn{2}{|c|}{ Total weed density } & \multicolumn{2}{|c|}{ Visible injury! } & \multirow[b]{2}{*}{ Cabbage yield } \\
\hline & & 3 WAP 2 & 6 WAP & 3 WAP & 6 WAP & \\
\hline & $\mathrm{kg}$ ai/ha & \multicolumn{2}{|c|}{ Plants $/ 0.5 \mathrm{~m}(\theta)$} & $\ldots \ldots$ & $\ldots$ & $\mathrm{kg} / \mathrm{ha}$ \\
\hline Clomazone & 1.12 & $20(91)$ & $42(83)$ & 25 & 10 & 15,680 \\
\hline Clomazone & 2.24 & $18(92)$ & $69(71)$ & 27 & 10 & 16,750 \\
\hline Oxyfluorfen & 0.28 & $17(92)$ & $38(84)$ & 15 & 2 & 13.980 \\
\hline Oxyfluorfen & 0.56 & $13(94)$ & $71(71)$ & 31 & 22 & 9.790 \\
\hline Prometryn & 2.00 & $11(95)$ & $54(78)$ & 78 & 65 & 410 \\
\hline Prometryn & 4.00 & $5(98)$ & $65(73)$ & 98 & 93 & 1,160 \\
\hline Handweeded & - & $0(100)$ & $6(98)$ & 0 & 0 & 25,390 \\
\hline Nonweeded & - & $212(0)$ & $241(0)$ & 0 & 0 & 280 \\
\hline LSD (0.05) & & 41 & 40 & 10 & 11 & 8.790 \\
\hline
\end{tabular}

Visual rating scale from 0 to 100 , with $0=$ no injury and $100=$ complete crop kill.

WAP = weeks after planting.

Percentage weed reduction as calculated from the nonweeded treatment. 
TABLE 3. - Plant density of three major weed species in cabbage treated with pre-transplant herbicides in $1992-93$ and 1994 at Juana Diaz, Puerto Rico:

\begin{tabular}{|c|c|c|c|c|c|c|c|}
\hline \multirow[b]{2}{*}{ Treatment } & \multirow[b]{2}{*}{ Rate } & \multicolumn{2}{|c|}{ Jimsonweed } & \multicolumn{2}{|c|}{ Junglerice } & \multicolumn{2}{|c|}{ Purple nutsedge } \\
\hline & & $1992-93$ & 1994 & $1992-93$ & 1994 & $1992-93$ & 1994 \\
\hline & $\mathrm{kg}$ ai/ha & $\ldots \ldots . . . .$. & $\ldots$ & ... Plants & $(\mathrm{c}) \ldots$ & . . . . . . . & $\ldots . . . . .$. \\
\hline Clomazone & 1.12 & $4(83)$ & $6(54)$ & $1(94)$ & $2(99)$ & $12(+300)$ & $24(+380)$ \\
\hline Clomazone & 2.24 & $1(96)$ & $3(77)$ & $1(94)$ & $2(99)$ & $9(+200)$ & $53(+960)$ \\
\hline Oxyfluorfen & 0.28 & $5(78)$ & $8(38)$ & $6(63)$ & $3(99)$ & $20(+567)$ & $24(+380)$ \\
\hline Oxyfluorfen & 0.56 & $3(87)$ & $12(8)$ & $2(88)$ & $2(99)$ & $18(+500)$ & $56(+1020)$ \\
\hline Prometryn & 2.00 & $5(78)$ & $7(46)$ & $19(+19)$ & $13(94)$ & $14(+367)$ & $31(+520)$ \\
\hline Prometryn & 4.00 & ]. (96) & $1(92)$ & $19(+19)$ & $8(96)$ & $16(+433)$ & $54(+980)$ \\
\hline Handweeded & - & $0(100)$ & $0(100)$ & $7(56)$ & $1(99)$ & $1(67)$ & $5(0)$ \\
\hline Nonweeded & - & $23(0)$ & $13(0)$ & $16(0)$ & $215(0)$ & $3(0)$ & $5(0)$ \\
\hline $\operatorname{LSD}(0.05)$ & & 11 & 9 & 1.1 & 17 & NS & 39 \\
\hline
\end{tabular}

'This evaluation was made six weeks after cabbage planting.

Percentage weed reduction as calculated from the nonweeded treatment. Numbers preceded by + symbol indicate increase in weed density as calculated from the nonweeded treatment. 
Clomazone and oxyfluorfen caused moderate injuries (15\% to $31 \%$ ) to cabbage at three WAP in 1994 (Table 2). Symptoms caused by clomazone decreased to $10 \%$ or less at six WAP. Injury symptoms for clomazone and oxyfluorfen treatments were not detected after nine weeks (data not shown). For the second year, prometryn caused over $65 \%$ stand mortality and reduced cabbage yield by more than $95 \%$. Cabbage treated with clomazone $(2.24 \mathrm{~kg}$ ai/ha) produced yields not significantly different from those of the handweeded treatment in 1994. Other yields were significantly lower than in the handweeded treatment.

Jimsonweed (Datura stramonium L.), junglerice [Echinochloa colona (L.) Lixk] and purple nutsedge were the predominant weed species in the experimental area for both years (Table 3). All herbicide treatments reduced jimsonweed density by $78 \%$ or more in 1992-93; however, only the highest rates of clomazone and prometryn reduced jimsonweed density by $77 \%$ or more in 1994. Junglerice density was reduced by more than $93 \%$ with both rates of clomazone, and by $88 \%$ with oxyfluorfen ( $0.56 \mathrm{~kg}$ ai/ha) in 1992-93. Junglerice was reduced by $94 \%$ or more by all herbicide treatments in 1994 when compared to nonweeded plots.

Purple nutsedge density was not significantly different among herbicide treatments in 1992-93 (Table 3). Plots treated with high rates of the three herbicides had higher purple nutsedge density than the nonweeded treatment in 1994. This weed generally invaded cabbage plots after other weed species were controlled with herbicides.

Clomazone and oxyfluorfen showed good potential for weed control in cabbage. In our experiments, clomazone and oxyfluorfen were effective for grass and broadleaf weed control, and cabbage transplants recovered from the initial injuries. However, prometryn was highly phytotoxic and reduced cabbage yield. The yield re iuction recorded in clomazone and oxyfluorfen treatments in 1994 can be attributed to weed interference, mostly from purple nutsedge.

\section{LITERATURE CITED}

Alamo, C. I., 1992. Estadísticas relevantes y tendencias de producción e importación de repollo en Puerto Rico p: 5-11 en: Foro Técnico: Cultivo y producción de repollo. Barranquitas, Puerto Rico. 14 Junio 1992.

Departamento de Agricultura, 1992. Anuario de estudísticas agrícolas 1990/91. Oficina de Estadisticas Agrícolas, Departamento de Agricultura, Santurce, Puerto Rico.

Herbst, K. A. and J. F. Deer, 1990. Effect of oxyftuorfen, pyridate and BASF 514 applied postemergence on direct-seeded broccoli (Brassica oleracea var. botrytis). Weed Technol. 4:71-75. 
Hopen, H. J., 1995. Herbicides available for commercial cabbage producers during 1965 94. Hort Technology 5:25-26.

Hopen, J. H., R. L. Hughes and B. A. Michaelis, 1993. Selectivity among cabbage (Brassica oleracea. L.) cultivars by clomazone. Weed Technol. 7:471-477.

Jackson, G. C., 1977. Evaluation of Hercules 22234 (Antor) as a preemergence herbicide on cabbage. J. Agric. Univ. P.R. 61:516-518.

Nuñez-Almario, G., 1984. Control químico de malezas en repollo. Información T'écrica. Rhom \& Hass 6:3-34.

Scott, J. E. and L. A. Weston, 1992. Cole crops (Brassica oleracea) tolerance to clomazone. Weed Sci. 40:7-11.

Scott, J. E., L. A. Weston and R. T. Jones, 1995. Clomazone for weed control in transplanted cole crops (Brassica oleracea). Weed Sci. 43:121-127. 